\title{
'The king in the car park': new light on the death and burial of Richard III in the Grey Friars church, Leicester, in 1485
}

Richard Buckley ${ }^{1}$, Mathew Morris ${ }^{1}$, Jo Appleby ${ }^{2}$, Turi King ${ }^{2,3}$, Deirdre O'Sullivan ${ }^{2} \&$ Lin Foxhall ${ }^{2}$

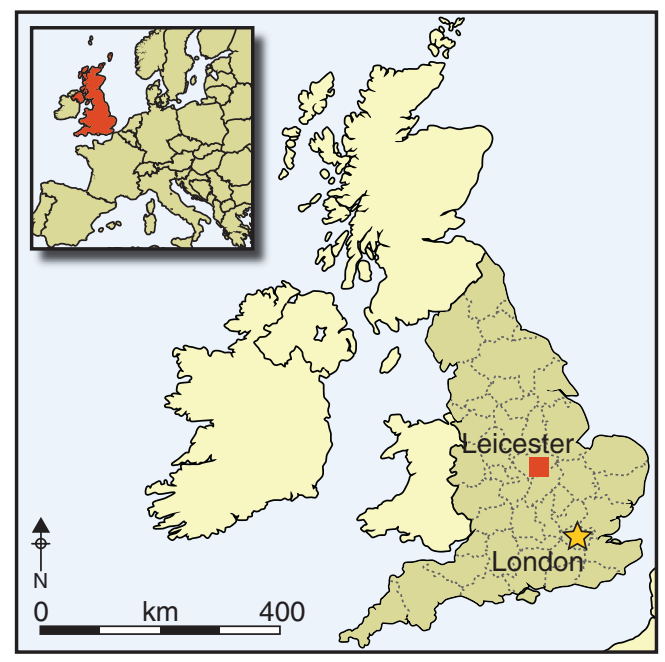
as the burial of the last Plantagenet king. This paper presents the archaeological and the basic skeletal evidence: the results of the genetic analysis and full osteoarchaeological analysis will be published elsewhere.

Keywords: Leicester, Grey Friars, 1485, Richard III, Battle of Bosworth

\section{Introduction}

Richard III (1483-85) is probably England's most familiar medieval king. Immortalised by Shakespeare and others as an infamous villain, but with a strong cohort of modern-day supporters, he has remained a highly controversial figure of both history and drama since his death.

\footnotetext{
University of Leicester Archaeological Services, University of Leicester, University Road, Leicester LE1 7RH, UK School of Archaeology and Ancient History, University of Leicester, University Road, Leicester LE1 7RH, UK

Department of Genetics, University of Leicester, University Road, Leicester LE1 7RH, UK 
King Richard was killed at the Battle of Bosworth, the culmination of the Wars of the Roses, on 22 August 1485 (Foarde \& Morris 2012: 91-95). Afterwards, the victor, Henry Tudor, now King Henry VII, brought Richard's naked body back to Leicester for public display, probably in the Church of the Annunciation of the Blessed Virgin Mary in the intra-mural religious precinct of the Newarke (BL Harley MS 542: f.34). On 25 August, the body of the defeated king was laid to rest with minimal funerary rites in the medieval church of the convent of the Friars Minor (the Franciscans, also known as the Grey Friars; Rous 1745 [1486]: 218; Halle 1970 [1550]: f. xxxv; Polydore Vergil 1972 [1555]: 25.25; Baldwin 1986: 21). Ten years later, King Henry VII had an alabaster tomb erected over the grave. The friary was dissolved by King Henry VIII in 1538 and most of the buildings were demolished soon after.

This paper reports the results of a public archaeology project initiated by Philippa Langley, a member of the Richard III Society, and executed by a team of archaeologists and other specialists from the University of Leicester. The aim was to locate the Grey Friars church in Leicester in which the body of Richard III is recorded to have been buried. The excavations discovered not only the friary church, but also a grave that may have contained the remains of Richard III. Following post-excavation analysis, in February 2013 it was announced that his skeleton had indeed been identified. Publicly acclaimed as the 'king in the car park', this conclusion takes account of the full spectrum of evidence retrieved from the site of the Grey Friars church in Leicester, currently a parking area for the City Council Social Services. This paper sets out the archaeological evidence for the site and for the identification of the burial as that of Richard III. It will not consider in detail the osteoarchaeological or genetic evidence, as the results of these investigations will shortly be published elsewhere by Jo Appleby and Turi King respectively.

The Grey Friars Project has been unusual in the nature of the collaboration between professional and academic archaeologists, an amateur group (the Richard III Society) and the City of Leicester. However, this also means that the project has addressed two different but overlapping sets of research questions, not all of which specialists would routinely ask. Projects developed in this way may become more common in future as nonspecialists increasingly become users, stakeholders and participants in academic research. What is somewhat different from the ways in which archaeological professionals and amateurs have generally worked together is that in this case the non-specialists played a role in shaping the intellectual frameworks of the project, although the final project design (including how questions could appropriately be asked of the evidence), and the execution of the project in practical terms remained in the hands of the archaeologists. Grey Friars offers a case study for addressing the issues of how to formulate multiple sets of research questions and aims, and how different kinds of partners can accommodate each other's questions.

For the Richard III Society, the key questions evolved out of a desire to provide Richard III's story with a more credible conclusion than Speed's fanciful seventeenth-century tale that his bones were dug up during the dissolution of the friary and thrown into the River Soar (Speed 1611: 725), hopefully by finding the monarch's grave. Although our non-specialist partners were interested in the wider context of the church and the medieval town, their primary concern was Richard himself.

(C) Antiquity Publications Ltd. 
For the University of Leicester Archaeological Services (ULAS), commissioned to carry out the research, the project presented an opportunity to find out whether evidence of the Franciscan friary and its church survived, and to investigate this important institution in medieval Leicester as part of the larger, existing research strategies and frameworks for the city and the region. The research questions and investigation strategy focused on understanding the layout of the friary precinct and locating the lost church building (see below). Initially, finding the grave of Richard seemed improbable if not impossible, if it had even survived at all. This strong likelihood was discussed with our non-specialist partners, to ensure that they understood the slim chances of success for this particular aim, even though it was clear that the project would certainly add much of value to our knowledge of medieval Leicester.

\section{Medieval Leicester}

In the late Anglo-Saxon period (tenth-eleventh centuries AD), settlement developed within the walls of the former Roman town and, by the time of Domesday in 1086, Leicester had six churches, 322 houses and a population of perhaps 3000 (Courtney 1998: 118-19). The twelfth-thirteenth centuries saw a boom in development, with the foundation of the abbey, the construction of the stone elements of the castle and the rebuilding of churches (Figure 1). Archaeological evidence has shown that by 1300, the intramural area is likely to have been fully occupied, but thereafter, starting in the early decades of the fourteenth century, the town seems to have suffered a decline leading to significant depopulation of a large part of the north-eastern quarter (Connor \& Buckley 1999: 90). The taxable valuation of Leicester in 1334 places it as a county town of medium rank (no. 38) whilst later, after the Black Death, recovery is suggested by the Poll Tax returns which show that the town had risen in the urban hierarchy (to no. 17) with a taxable population of 2302 (Glasscock 1975: 158; Dyer 2000: 758).

Notwithstanding, the suburbs seem to have expanded and the Earls, later Dukes, of Lancaster established an extramural religious precinct known as the Newarke with a college of canons, the church of the Annunciation of the Blessed Virgin Mary and a hospital. After 1399, the Dukes of Lancaster became kings of England (in the person of Henry IV) and there was a major building programme at the Newarke during the first quarter of the fifteenth century; the church there effectively became a Lancastrian mausoleum. Three houses of friars were founded in the thirteenth century (Figure 1): the Dominicans or Blackfriars in the north-western corner of the walls; the Augustinian friars outside the west gate, on an island between two arms of the river Soar; and the Franciscans, or Grey Friars, the most centrally located in the southern part of the town, close to the Saturday market.

Grey Friars was the earliest of the Leicester friaries, founded c.1224-30 (Little 1951: 38). The first explicit reference to its church dates to 1255 when Henry III, at the urging of Eleanor, Countess of Leicester, granted 18 oak trees to the Friars Minor of Leicester "for stalls to be made, and to wainscot their chapel" (Calendar of the Close Rolls 1254-56: 244), implying the near-completion of their church. The friary sprang to prominence in 1402 when five friars along with brethren from Northampton and Nottingham were executed for treason, for spreading seditious rumours, denying the legitimacy of Henry IV's rule and for providing money to Welsh rebels (Marx 2003: 30-32); otherwise its history was

(C) Antiquity Publications Ltd. 


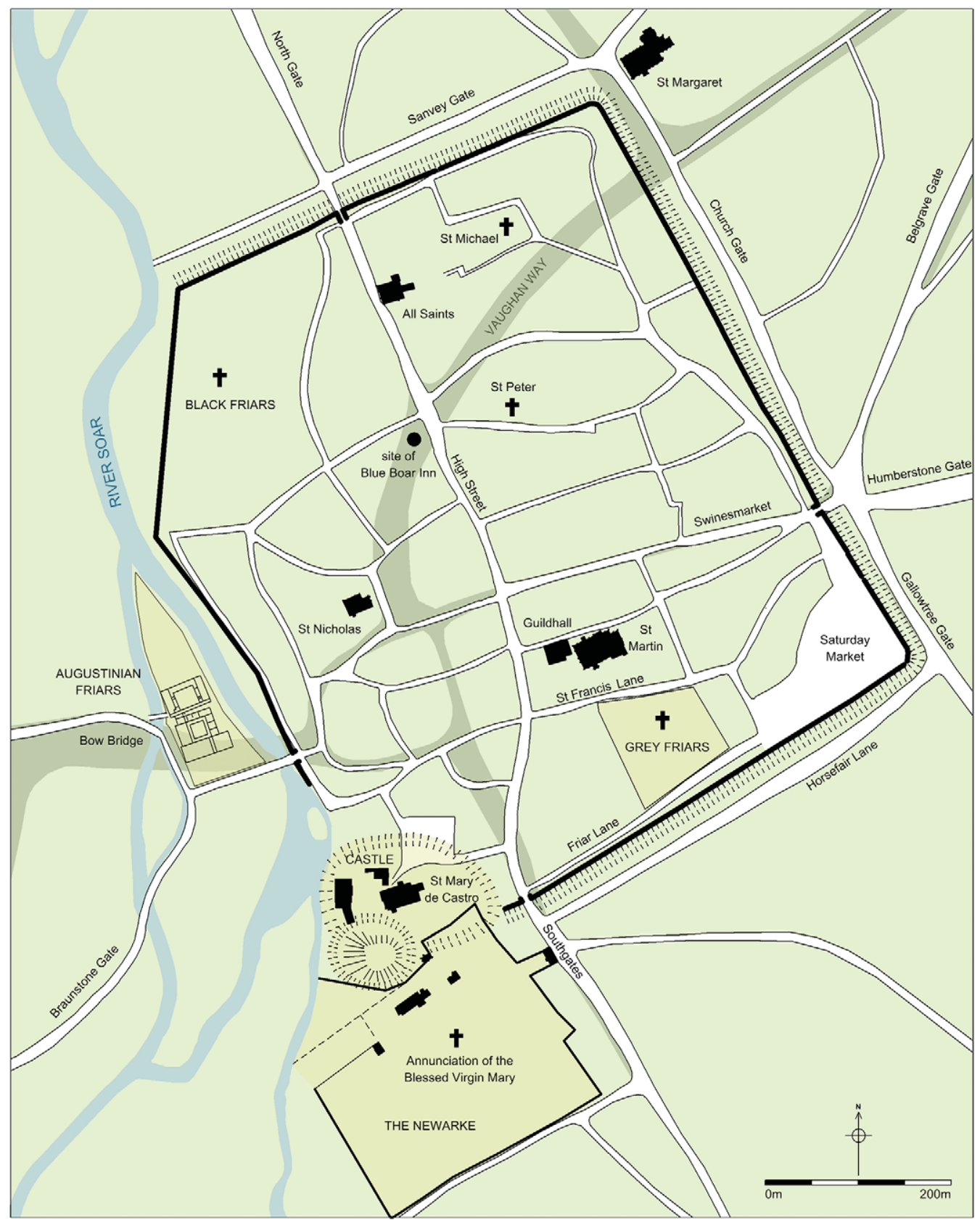

Figure 1. Map of medieval Leicester.

uneventful until the choir of its church was chosen as the burial place of King Richard III (Rous 1745 [1486]: 218). Seven friars signed the surrender of the house in 1538 and most of the buildings were demolished soon after (Nichols 1815: 294).

(C) Antiquity Publications Ltd. 
In the early seventeenth century, the land was owned by Robert Herrick, a former mayor of Leicester, who built a large house and garden on the site. In his garden, Herrick erected a memorial pillar inscribed "here lies the body of Richard III sometime King of England" (Baldwin 1986: 22). As Leicester flourished and expanded during the ensuing centuries, Herrick's land was gradually sold off, sub-divided and built on, and the precise location of the church and the grave became lost.

\section{The Grey Friars excavation strategy}

Although the general area of the precinct was well-known and verified, the arrangement and location of the friary buildings were not. A number of constraints and possibilities were identified which helped to define the excavation strategy. Archaeological deposit models derived from the extensive excavations undertaken in Leicester over the past 50 years suggested that post-medieval levels and modern overburden together were likely to amount to around $700 \mathrm{~mm}$ in thickness (Lucas 1980-81). There was no great expectation, however, that the friary would be well preserved. Owing to the lack of good local building stone, medieval walls in Leicester are normally found to have been extensively robbed of material from both superstructure and foundations, and floors rarely survive in good condition. In addition, although a relatively standard plan for the religious house might be expected, with a church to the north of a range of cloistral buildings, friaries were adapted to suit urban topography. The most important factor in the location of the church was usually public accessibility, and it was therefore normally located close to a major thoroughfare with the cloistral ranges, which were often comprised of two courts, on the side away from this (O'Sullivan 2013a:15). Leicester's Augustinian friary, for example, excavated in 1973-78, had two cloisters and a church to the south (Mellor \& Pearce 1981).

In 2011 Philippa Langley, as an outcome of discussion with ULAS, commissioned a deskbased assessment of the Grey Friars area of Leicester (Hunt 2011). The research of Billson (1920) and Baldwin (1986) has shown that the friary precinct is today broadly defined by the streets Grey Friars, Friar Lane, New Street and St Martin's (Figure 2). This was further refined by ULAS's map regression analysis (Hunt 2011). Two medieval streets bound the Grey Friars site, St Martin's to the north and Friar Lane to the south (Figure 1), but it was not clear on which of these the church was sited, and the information provided by texts is unhelpful (Hunt 2011; Morris 2013).

The earliest surviving map to show accurate detail of the area, Thomas Roberts' map of 1741, clearly marks the 'Gray Fryers' precinct (Figure 3), further refining the search. Comparison with later maps showed that while much of the precinct is today covered by eighteenth- to twentieth-century redevelopment, the area still contained several open spaces (mostly car parks), which had not apparently been built over since the friary's dissolution in the sixteenth century.

A GPR survey in 2011 failed to reveal clear wall lines or other features, although it helped to identify modern services (Austrums 2011). Against this background, the 2012 excavation project initially proposed to examine two overlapping $30 \mathrm{~m} \times 1.6 \mathrm{~m}$ trenches in the Social Services car park (Trenches 1 and 2; Figure 2), both oriented north-south in order to transect

(C) Antiquity Publications Ltd. 


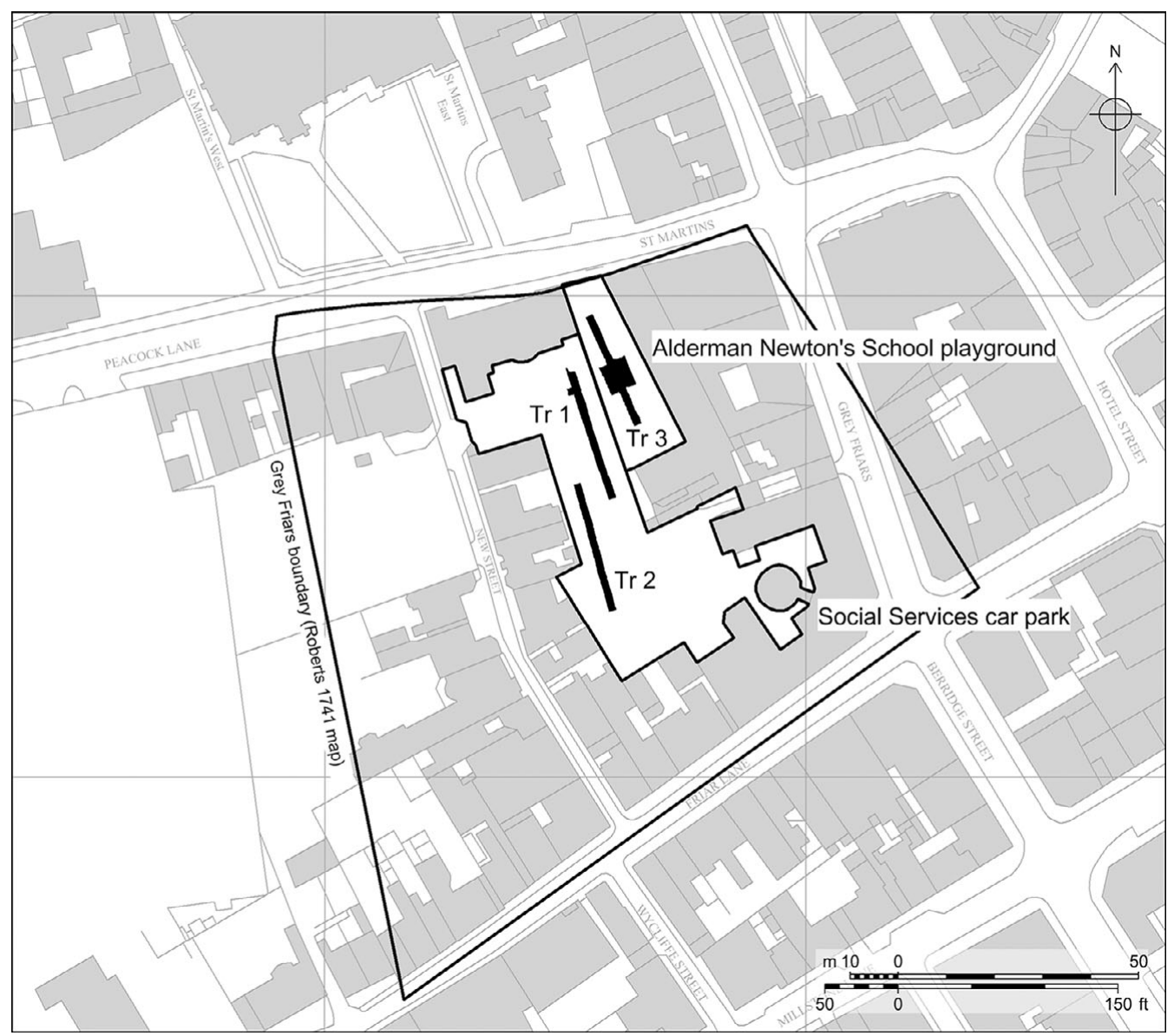

Figure 2. Location plan, Grey Friars.

as much of the site as possible. This provided the best chance of picking up the church and other friary buildings, of which many would be expected to be oriented east-west.

Trench 3 was opened slightly later in order to explore more fully the archaeology east of the northern end of Trench 1, where the medieval deposits were highly truncated and difficult to interpret. Subsequently, selected areas of Trench 1 and Trench 3 were widened in order to expose what proved to be the grave of the king, and to examine a particularly good stratigraphic sequence.

\section{The 2012 excavation}

The key aims were to find evidence of the buildings, to understand their location in relation to each other in the overall plan, and to discover any traces of the activities carried out on the site of one of Leicester's medieval urban friaries. Within these aims, one of the project's greatest challenges was to establish with reasonable certainty which specific areas of the friary had been revealed. Locating the choir of its church and, if it survived, King Richard (C) Antiquity Publications Ltd. 


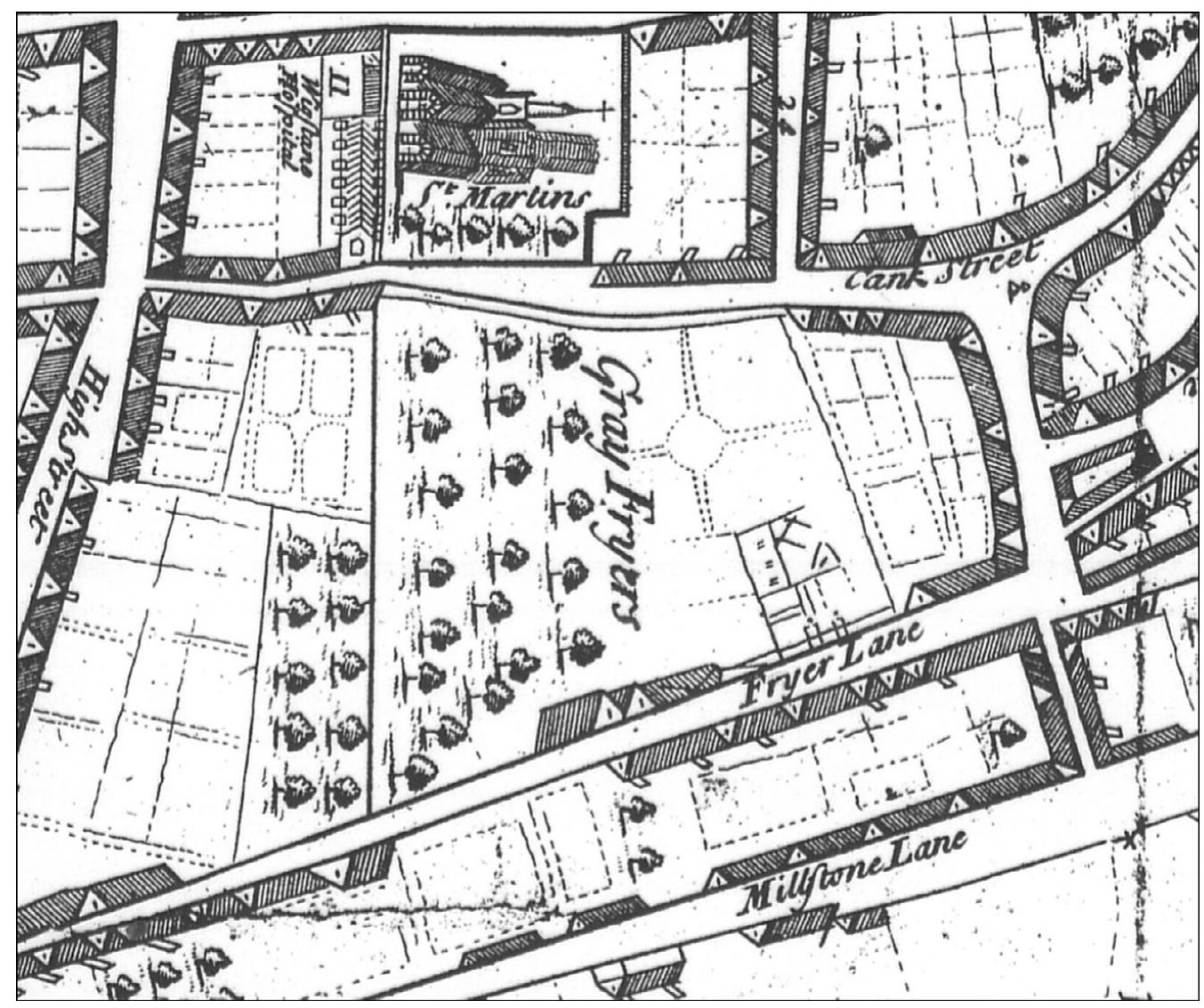

Figure 3. Extract from Roberts' 1741 map of Leicester.

III's tomb, was a priority. Due to the small scale of the excavation little can be definitively established about the friary's development, but evidence of the buildings sufficient to identify some elements of the friary and its church was found in all three trenches (Morris 2013).

\section{The cloistral buildings (Figure 4)}

Evidence for the cloistral buildings was found in Trenches 1 and 2. One structure, at the southern end of Trench 1, was quickly identified as the chapter house, typically sited on the eastern side of the friary close to the church. Parallel robbed east-west walls were found, against which shallow stone benches had been built, and fragments of mortar bedding for a tiled floor; no tiles were in situ but their impressions showed that they had been laid in a diamond pattern. The building was $c .7 .62 \mathrm{~m}$ wide and over $7 \mathrm{~m}$ in length. It appears to have been built of local grey sandstone and, based on the finds of building materials, was perhaps roofed with local slate with glazed ridge tiles. The identification of benches (Figure 5) placed against the walls was critical to interpreting the building's function. Chapter houses hosted daily meetings of the monastic community and were typically arranged with seating around

(C) Antiquity Publications Ltd. 


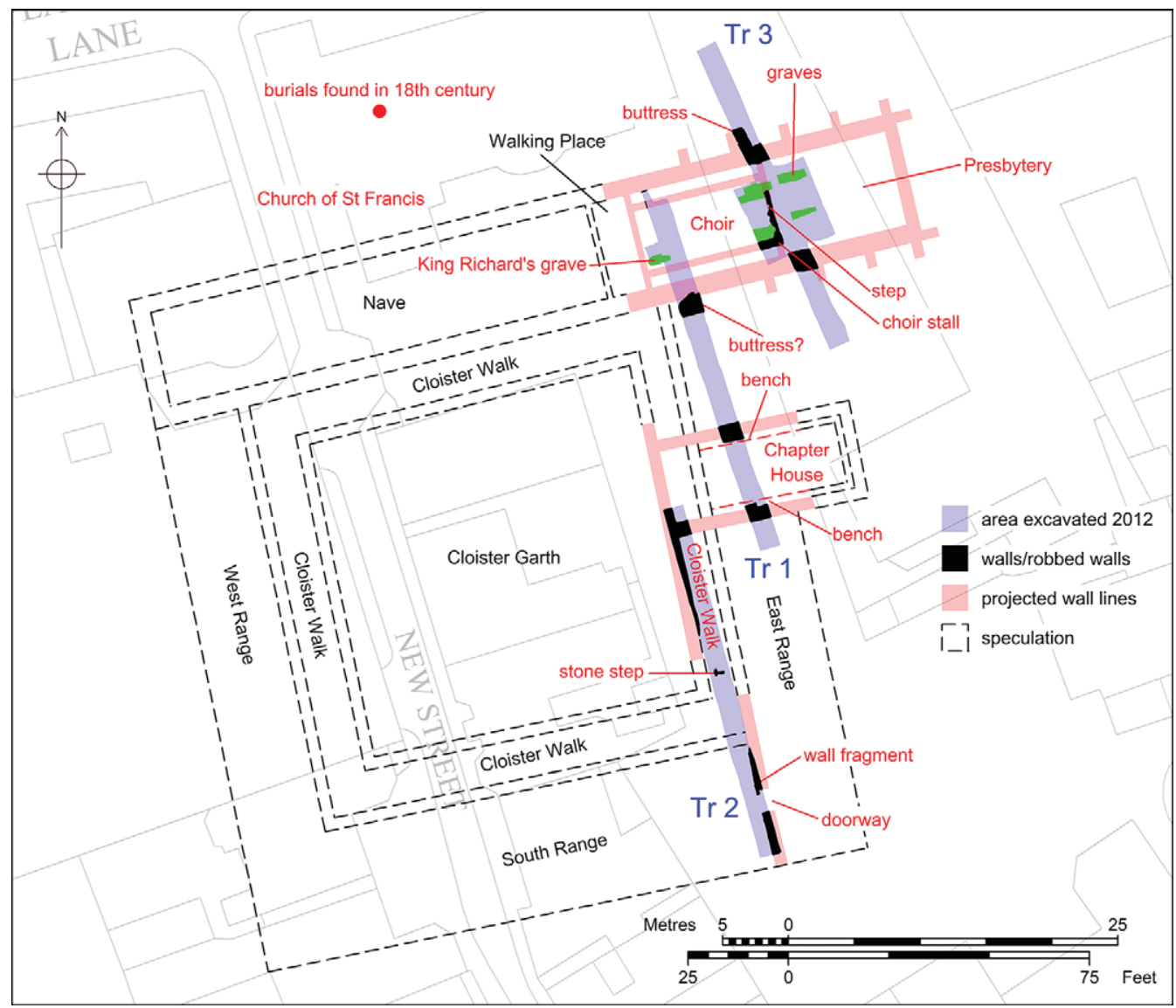

Figure 4. Interpretation plan, Grey Friars.

the walls (Greene 1992: 7). No evidence for buildings between the chapter house and church was found and the east range appears to have stopped short of the church.

South of the chapter house, in Trench 2, evidence of a building range and perhaps a north-south cloister walk was located. On identification of the chapter house, this was fixed as the eastern cloister walk. The evidence, two robbed walls spaced $c .2 \mathrm{~m}$ apart, with a robbed tiled floor between them (Figure 6), extended south for at least $25 \mathrm{~m}$ from the south wall of the chapter house. If this is the cloister walk it was quite narrow, and therefore of the pentice type, rather than undershot below the first floor apartments. That in itself is not unusual (O'Sullivan 2013a:15). The cloistral buildings appear to have been floored only once; the surviving tiles show considerable wear, in contrast to the church which has multiple periods of renovation. This may reflect the poverty of the brethren themselves. Tile fragments recovered from the demolition rubble over the cloistral buildings suggest that these were predominantly monochrome Chilvers Coton fabrics produced locally near Nuneaton in Warwickshire, $27 \mathrm{~km}$ south-west of Leicester.

(C) Antiquity Publications Ltd. 


\section{The church}

Trench 3 confirmed that the eastern end of the church was indeed to the north of the cloistral buildings, providing structural evidence for a large buttressed building approximately

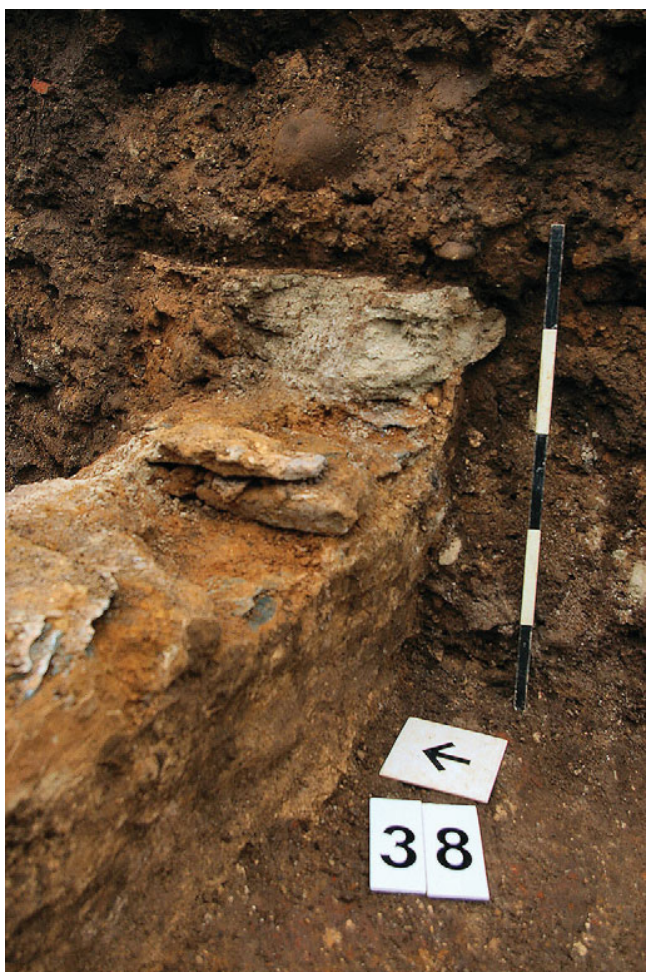

Figure 5. The northern stone bench, with a 'bullnose' lip to the seat, in the chapter house, Trench 1. $10.4 \mathrm{~m}$ wide with substantial stone footings. Inside, there were at least three phases of flooring, a series of shallow walls and steps, and at least three graves, one containing a stone coffin (Figure 7). None of these graves was excavated, as that was deemed beyond the remit of this small and limited phase of the project. Highly decorated floor tiles, lead window came, copper alloy letters (thought to be from tomb inscriptions) and fragments from a large early perpendicular window of the fifteenth century all suggested that this was almost certainly the church's eastern end.

The position of the choir seating in Trench 3 was determined by a c. $0.4 \mathrm{~m}$ wide wall on the south side of the church, set in $c .0 .8 \mathrm{~m}$ from the southern wall. This probably supported a suspended floor and timber stalls, first documented in AD 1255 (Calendar of the Close Rolls 1254-56: 244). Graves positioned close to the northern side of the wall suggest that the stalls initially contained only one row of seats. However, renovations associated with the last phase of flooring

widened the stalls, possibly making enough room to accommodate two rows of seating (Figure 8).

The eastern end of the choir was marked by a step up in floor levels into a large open space at the eastern end of the church, serving as the presbytery, which would originally have contained the high altar. Evidence for the choir seating only appears with a second phase of flooring, whilst the step does not appear until the third phase. Although no third phase floors survived intact, the mortar bedding for the floor tiles remained. This further underpins the notion that the eastern and western sides of Trench 3 represent two different spaces in the church. In the choir, to the west, tiles were laid parallel with the walls, whilst in the presbytery they were set in a diamond pattern. Floor tiles recovered from the rubble over the church were overwhelmingly inlaid, of the stabbed Wessex type. Such tiles matched the bedding impressions in the choir, but impressions in the presbytery indicate a much larger type of tile, none of which have been found to date.

(C) Antiquity Publications Ltd. 


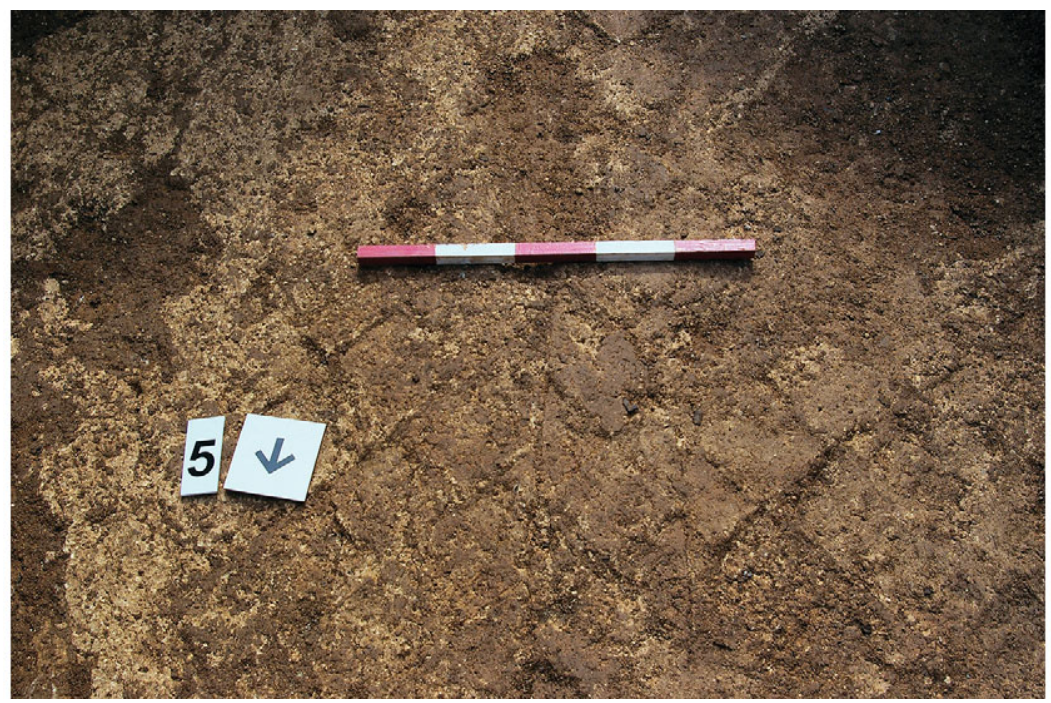

Figure 6. Tile impressions left on mortar bedding in the eastern cloister walk in Trench 2, looking south.

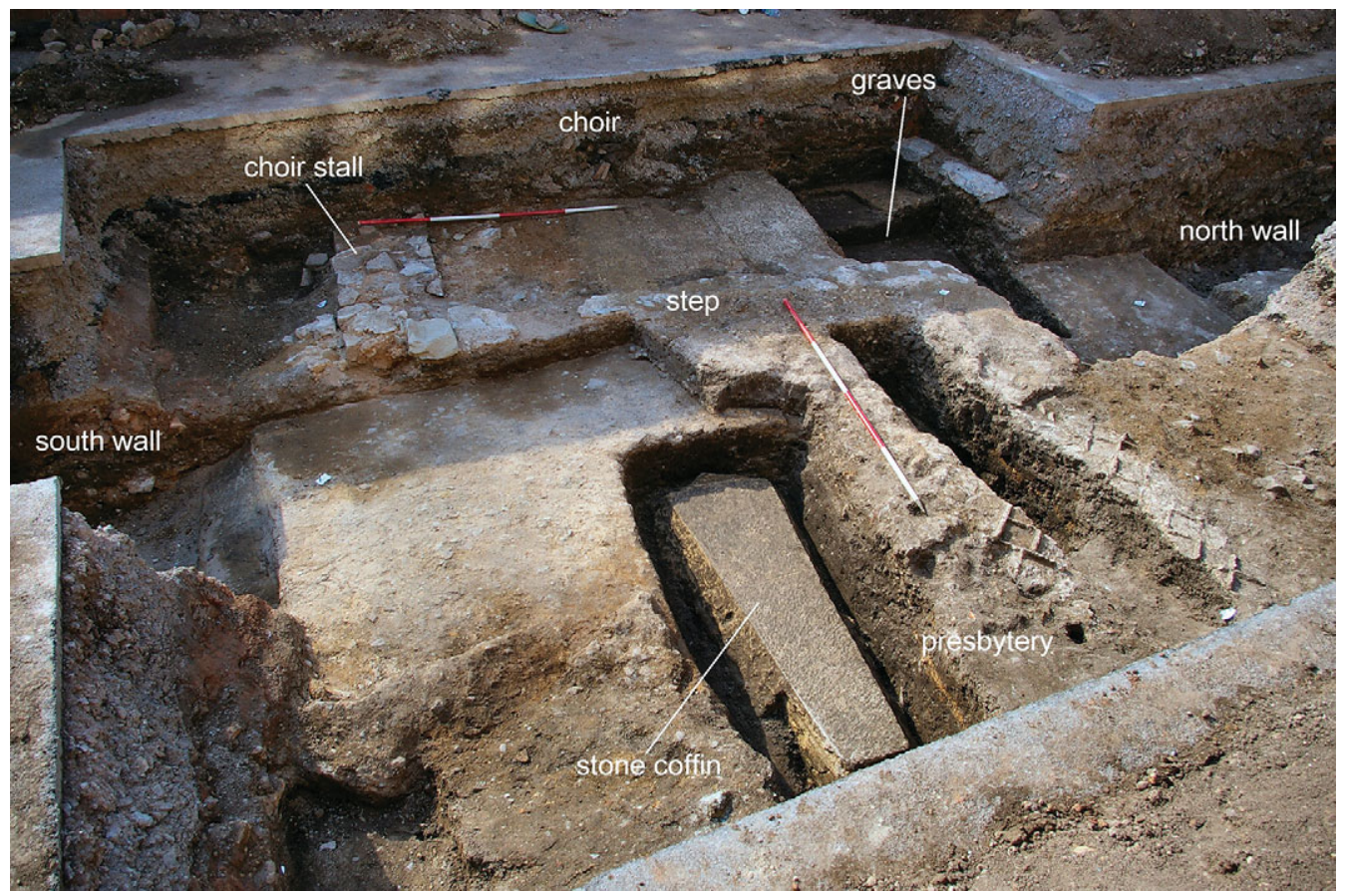

Figure 7. Trench 3, looking west.

Several large, rubble-filled rectangular voids in the floors of the choir and the presbytery are probably where tombs or grave slabs have been deliberately removed. In the choir these were located against the choir stalls. One void against the northern wall of the church in the presbytery produced a small group of Lombardic-style (c.1270-1350) copper alloy letters, (C) Antiquity Publications Ltd. 


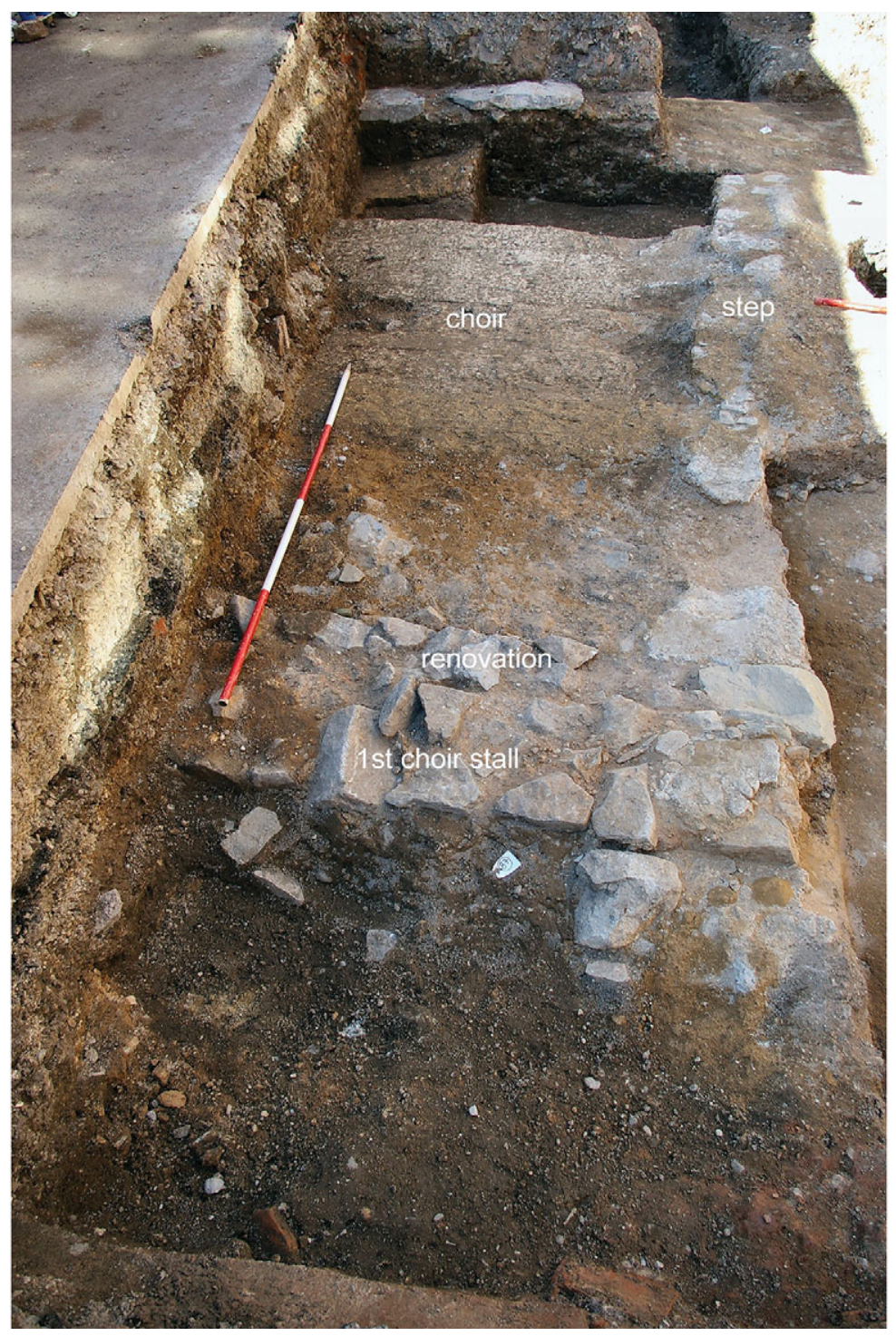

Figure 8. The church choir, looking north.

most likely lost from tomb inscriptions. Beneath the voids grave cuts could be identified. Significantly, none of the graves appears to have been disturbed during the destruction of the church, defacement being confined to floor level only.

Our understanding of the plan of the church is currently hampered by lack of evidence for the location of the nave and of the walking-place (Figure 4), a cross passage separating the choir and nave, often supporting a belfry, and a distinctive feature of friary architecture (Martin 1937). The choir appears to be long and narrow, typical of mendicant churches, but we have accurate dimensions only for its width, around $10.4 \mathrm{~m}$. On the grounds that the choir is present in both Trench 1 and Trench 3, it is at least $10 \mathrm{~m}$ long, with the presbytery

(C) Antiquity Publications Ltd. 
at least $4 \mathrm{~m}$ in length. This would make the eastern end of the church at least $14 \mathrm{~m}$ long. The arrangement is similar to that of the more extensively excavated Franciscan friary in Carmarthen, Wales. Here the choir stalls were constructed on similar walls which stopped around $10.4 \mathrm{~m}$ short of the east end of the church. The choir and presbytery were $11.4 \mathrm{~m}$ wide and at least $25 \mathrm{~m}$ long (James 1997: 114-17).

From Trench 3, the church could be projected back across Trench 1, where the same sequence of flooring and the robbed-out north wall and choir stall were present in section behind modern disturbance. A massive robbed wall footing in Trench 1 just south of the projected south wall line from Trench 3 may be the footing for a buttress, like one partially visible on the north wall in Trench 3 .

As yet, the access to the church from the cloistral buildings is unclear. Projected wall lines for the latter suggest the access would most likely occur outside the area excavated, west of Trench 1 . However, as the walking-place was not found during the excavation, this remains speculative. Floor levels in the church differed noticeably from those in the cloistral buildings. If buildings around the cloister were similar in level to the chapter house, as evidence from floors in Trench 2 indicate, there must have been at least two steps up into the church. Successive church floors were even higher. By the last phase of flooring in the church, the choir was around $0.6 \mathrm{~m}$ higher than the chapter house, a difference suggesting at least three or four steps down from one to the other.

Stains of brick dust found on masonry fragments, including a distinct line marking the plane of the wall on a piece of hoodmould, suggest that the eastern end of the church may have been built or faced in brick. This would have given the building a striking appearance, with off-white limestone tracery windows framed in red brick; quite a contrast to the pale grey sandstone walls of the cloistral buildings. If the eastern end of the church was partially built of brick, this would place it among the earliest medieval brick buildings in Leicestershire (Buckley et al. 2006: 21-24).

\section{Dissolution}

Little is known about the friary's last 43 years up to its dissolution in 1538 . By this time the friars were very poor, subsisting largely on alms, and a record of the friary's value lists a sum total of $£ 14 \mathrm{~s}$. Over the next 20 or more years (records list building material still being taken from the friary as late as 1561), the friary was stripped of all valuable materials (Nichols 1815: 294).

This destruction was readily apparent across the site. Little trace of the friary buildings remained, even below floor level, with much of the stone from the walls and foundations removed for use elsewhere. However, thick spreads of discarded building rubble sealed the medieval archaeology. Destruction of the church appears to have been particularly thorough, most likely conducted soon after the final surrender; soil accumulating inside the cloister buildings suggests that they had been rendered roofless and uninhabitable but left standing as ruins until a need for their stonework was found. No evidence of continued occupation of the buildings after the dissolution was found, although this cannot be ruled out entirely, on the basis of the small area so far explored.

(C) Antiquity Publications Ltd. 


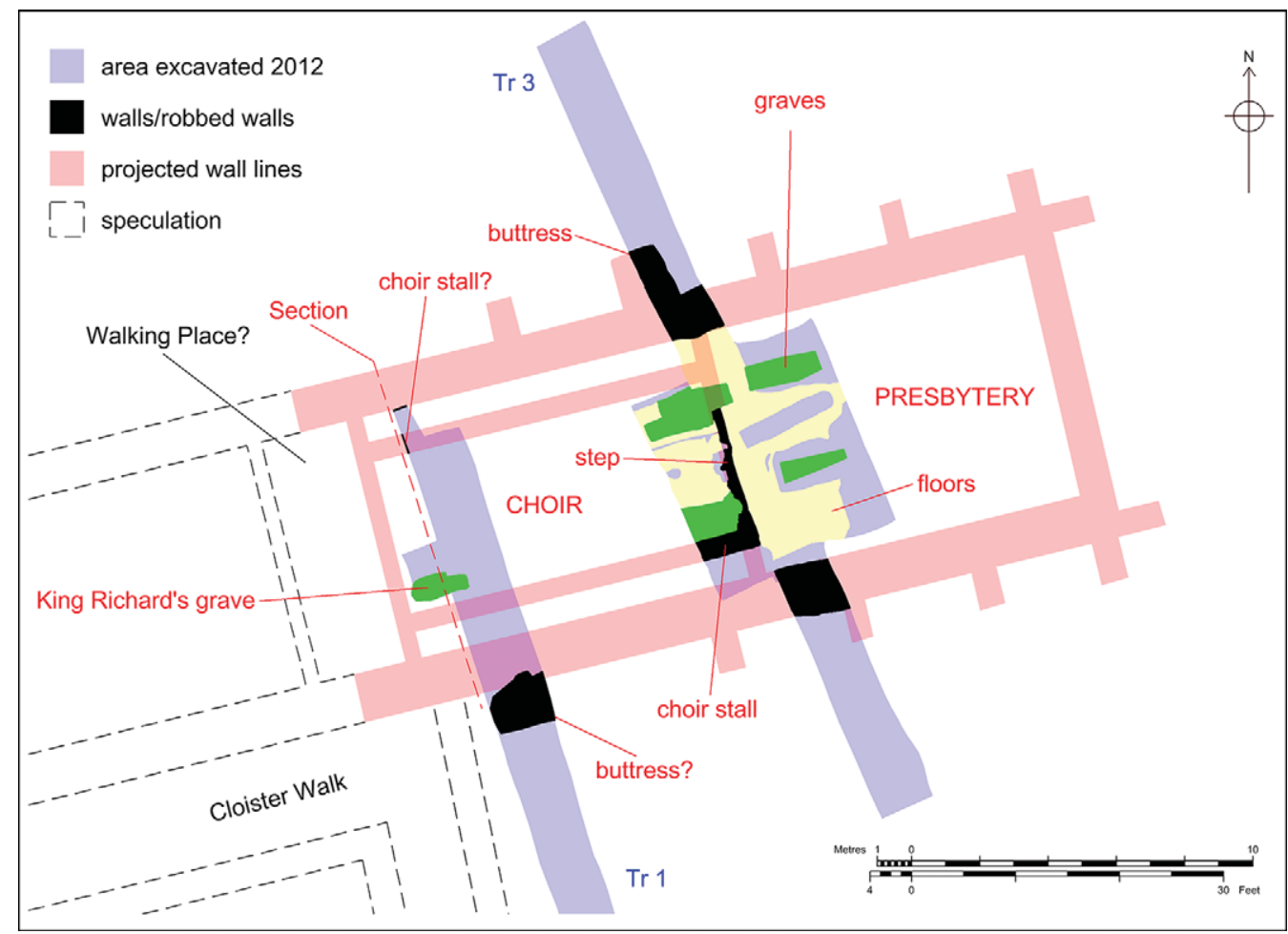

Figure 9. Interpretation plan, Grey Friars church choir.

\section{King Richard III's grave}

The grave identified as that of King Richard III was located in Trench 1 in the south-western sector of the choir, most likely against the southern choir stall (Figures $9 \& 10$ ). According to contemporary accounts, Richard III was buried without any pomp or solemn funeral (Polydore Vergil 1972 [1555]: 25.25; Baldwin 1986: 21). The archaeology of the grave, and the position of the body in it, reflect this.

The body appears to have been placed in the grave with minimal reverence. Although the lower limbs are fully extended and the hands lay on the pelvis, the torso is twisted to the north and the head, abnormally, is propped up against the north-west corner of the grave (Figures $11 \& 12$ ). Irregular in construction, the grave is noticeably too short for the body. Unlike other graves in the choir and presbytery in Trench 3 (Figure 13), which were of the correct length and neatly rectangular with vertical sides, this grave was an untidy lozenge shape with a concave base and sloping sides, leaving the bottom of the grave much smaller than its extent at ground level. Even in the relatively poor parish church of St Peter's, in Leicester's north-eastern quarter, graves inside the church were neatly squared, dug to the correct length and the interred provided with coffins (Gnanaratnam 2009: 105). Only a little extra effort by the grave-diggers to tidy the grave ends would have made this grave long enough to receive the body conventionally. That they did not, instead placing the body on one side of the grave, its torso crammed against the northern side, may suggest haste or little respect for the deceased. 
'The king in the car park'

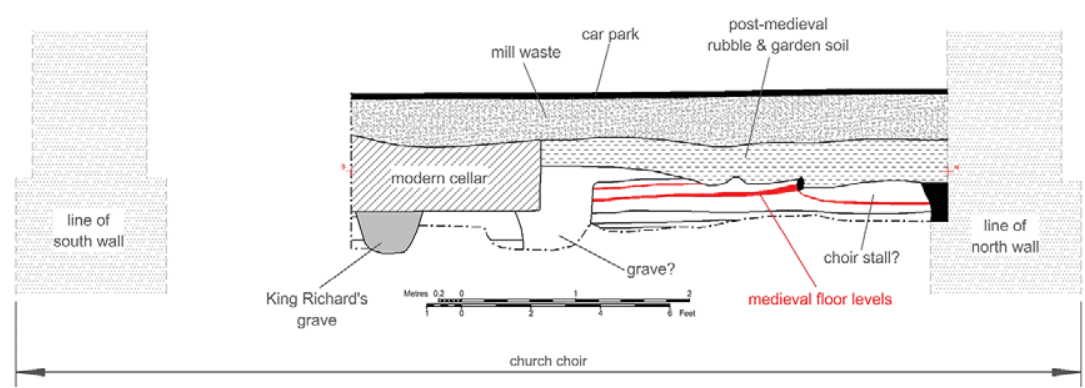

Archaeological evidence

(Trench 1)

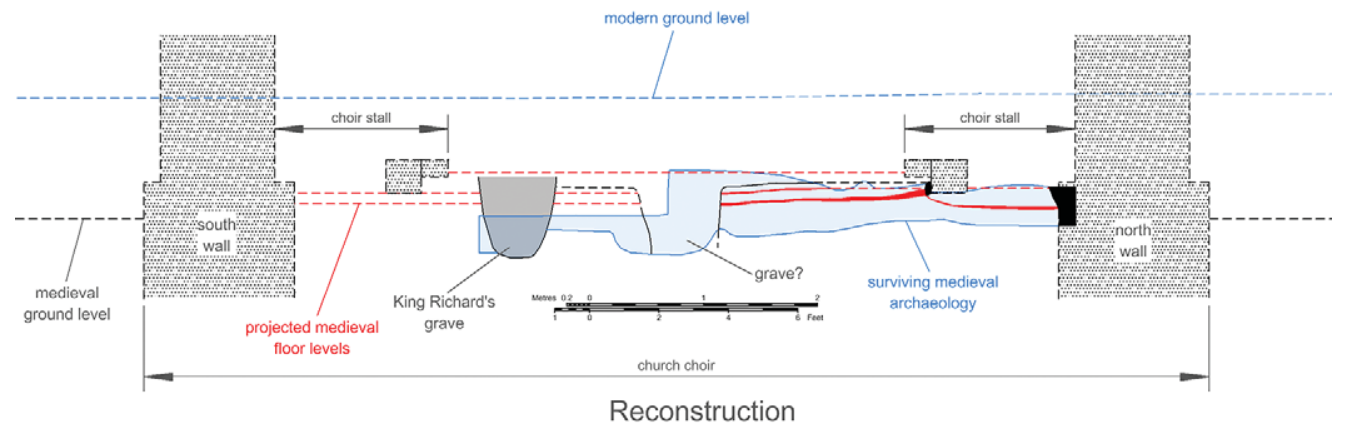

(based on evidence from Trench 1 and Trench 3)

Figure 10. Interpretive cross-section through the church choir.

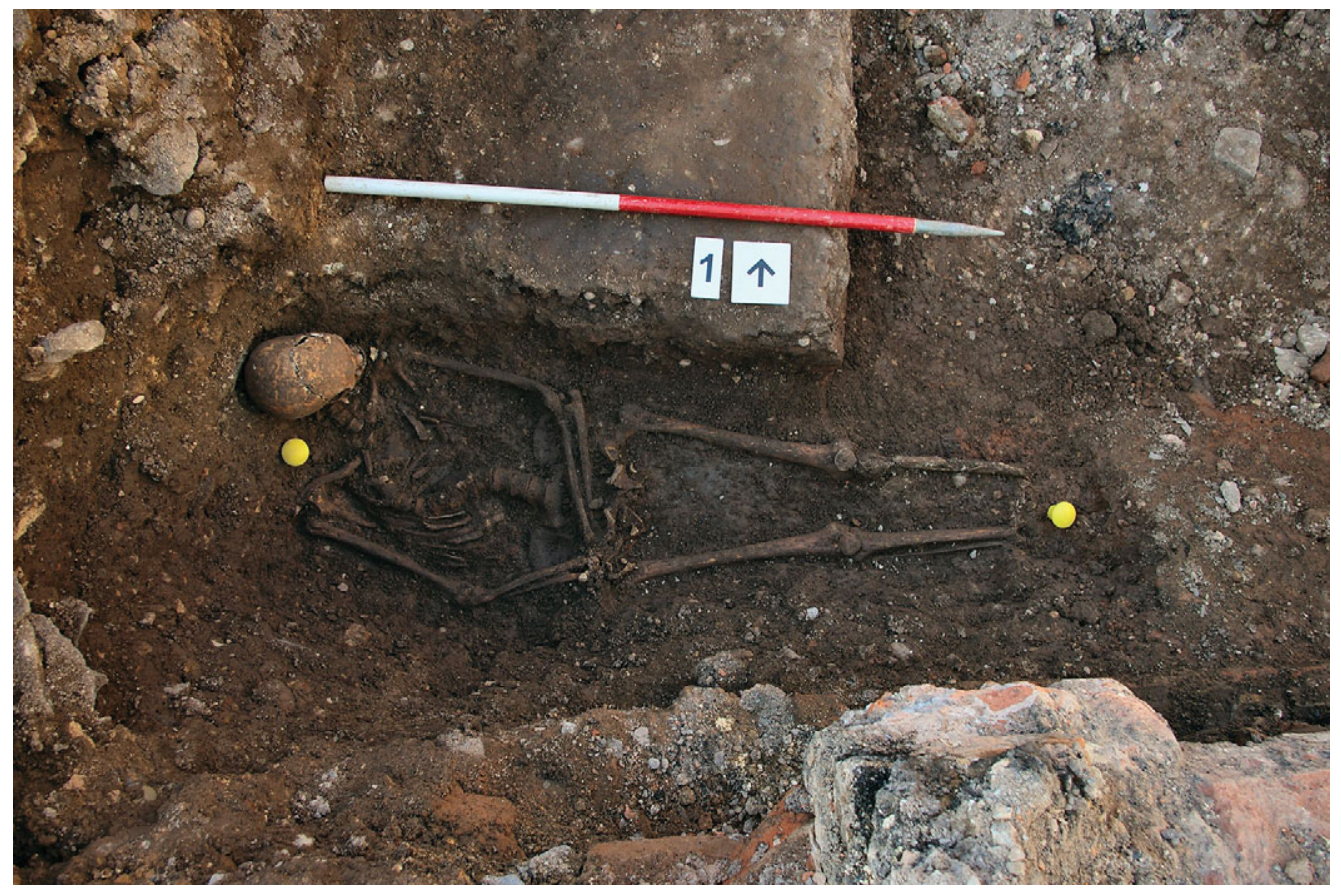

Figure 11. King Richard III's grave, with human remains in situ, looking north.

(C) Antiquity Publications Ltd. 


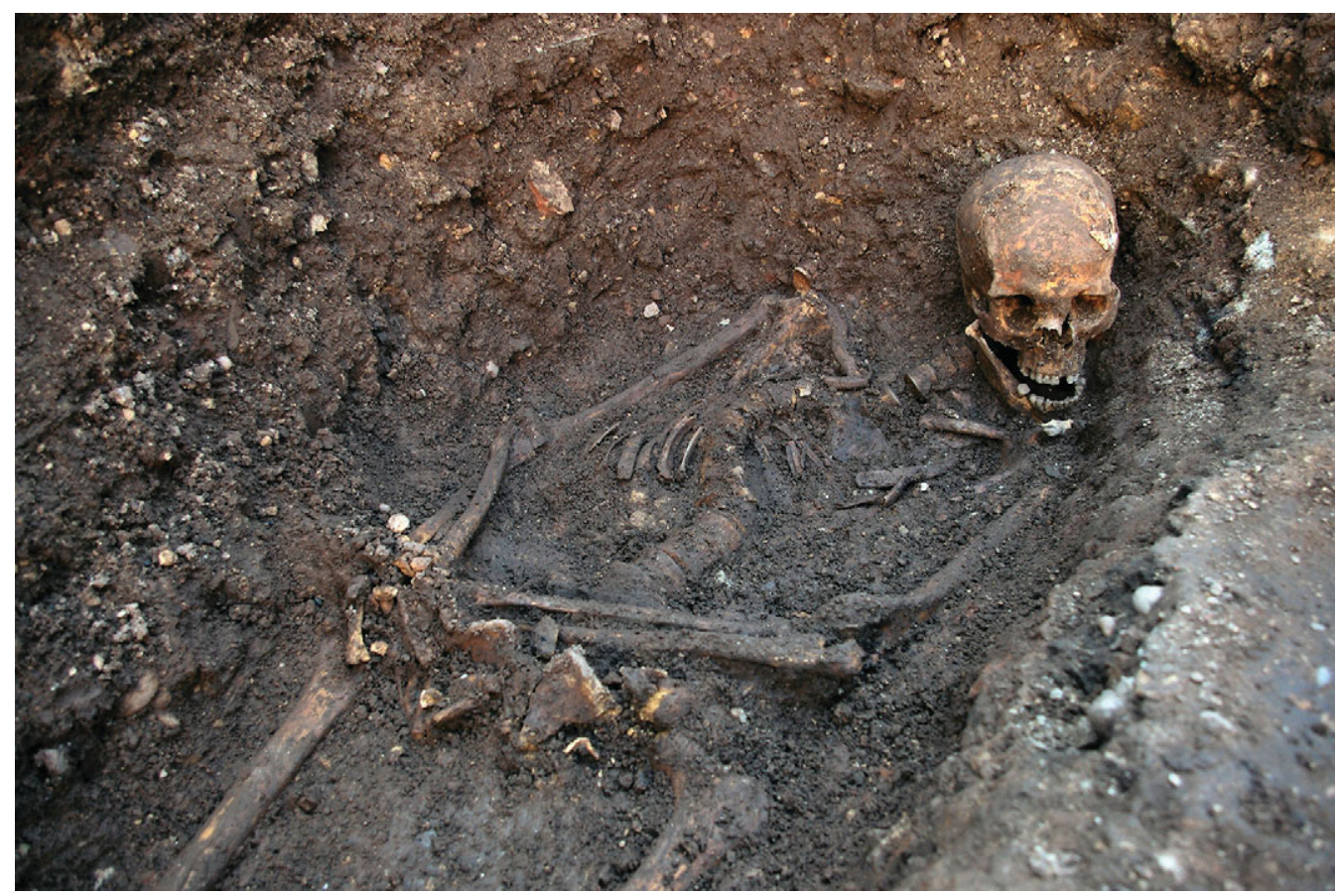

Figure 12. King Richard III, an oblique view looking west.

The significance of the choir as the chosen burial place is ambiguous. It is one of the more important areas of the church (though not as high in status as the presbytery), commonly reserved for the burial of important individuals and highly visible to the friars attending divine office. The choir of a friary church was not generally accessibly to the laity, however, thereby hindering public veneration of the tomb.

Friaries typically 'attracted' burials of affluent townsfolk and their specific patrons, which could include both royalty and nobility. It is true that Richard III is the only king to remain buried in a friary; although the deposed and murdered Richard II (d.1400) was initially laid to rest at the Plantagenet Dominican foundation at Kings Langley, his body was translated to Westminster in 1419 by Henry V. Perhaps significantly, friaries frequently seem to have served as resting places for the executed dead, where these were of high standing (O'Sullivan 2013a:11).

There was no evidence for a shroud or coffin. Wrapping a body in a shroud, common practice in medieval Leicester, often draws the limbs tightly together and skeletons which exhibit a compact longitudinal appearance are often deemed to be shroud-wrapped. Wooden coffins are common. Their shape is usually distinguishable in the grave soil with nails marking where coffin boards were fixed together. In this grave, the casual position of the body-legs slightly apart, shoulders expanded, arms flexed-certainly suggests the absence of a tight shroud, and perhaps the absence of any burial wrapping at all (Duday 2009: 45). As is common in most medieval burials, no trace of clothes, other goods or personal ornaments was found (O'Sullivan 2013b), although evidence from the mid thirteenth century onwards

(C) Antiquity Publications Ltd. 

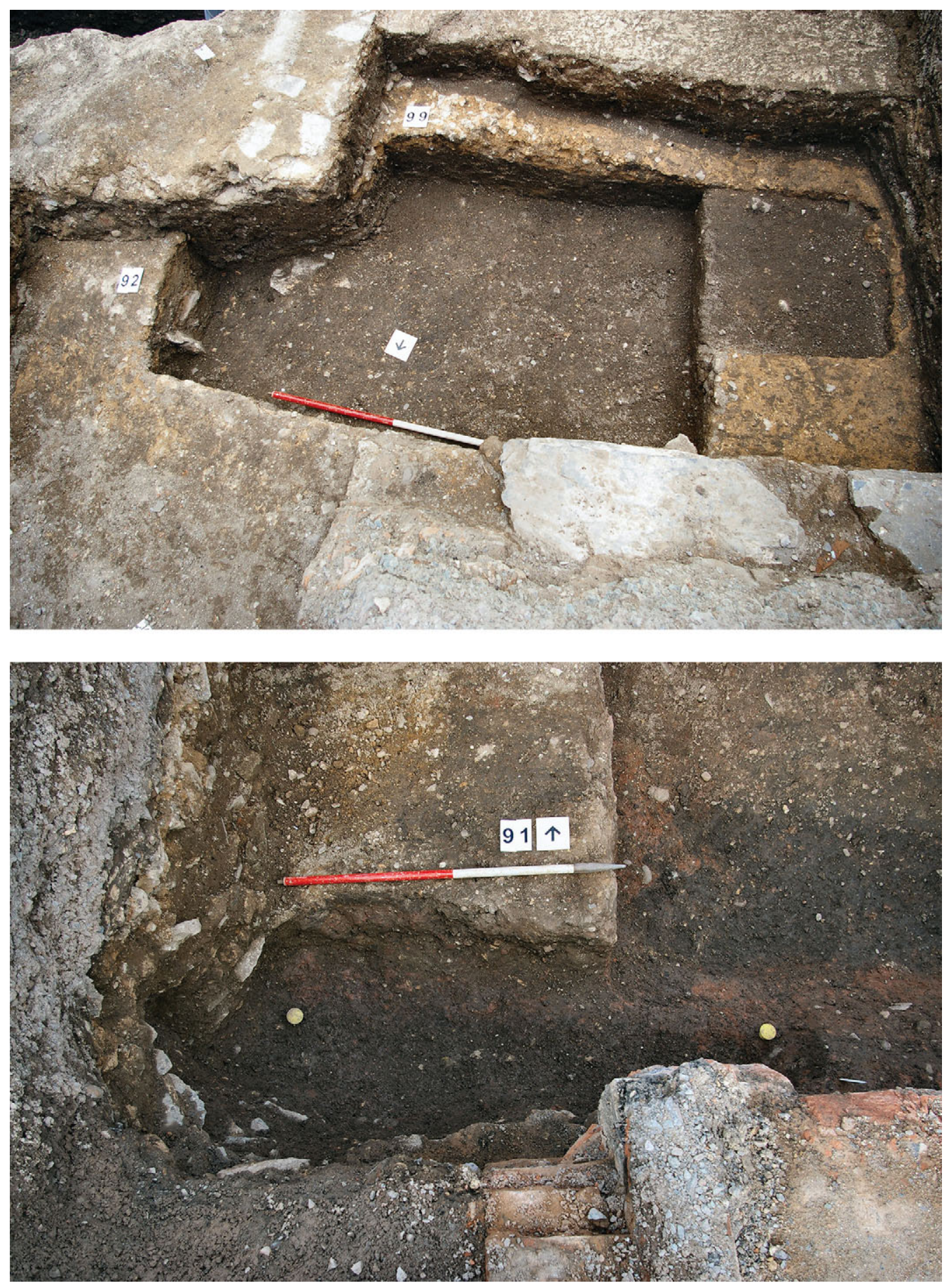

Figure 13. Graves on the northern side of the choir in Trench 3, looking south (top), and King Richard's grave after excavation, looking north (bottom).

(C) Antiquity Publications Ltd. 
shows that eminent people, particularly ecclesiastics and royalty, were often buried in their 'official' robes with emblems of office (Gilchrist \& Sloane 2005: 80-84).

One nail, probably residual and Roman in date, was discovered in the grave beneath the skeleton's thoracic vertebrae. On the basis of an initial, low-resolution X-ray this artefact was first interpreted as an arrowhead, but subsequent higher-resolution imaging disproved that. Residual Roman pottery, along with a small quantity of thirteenth-century pottery, was also present in the grave soil.

The odd position of the body can be explained by the mechanics of lowering a corpse into a grave. From the late fourteenth century, illustrations typically show one or more persons standing in the grave to receive the shrouded body or coffin (Gilchrist \& Sloane 2005: 26 $\& 152$ ). That the body is at one side of the grave rather than placed centrally may indicate that someone was standing in the grave to receive it.

The final arrangement suggests Richard III's body was lowered feet first, torso and head second. This would account for the neat extended position of the legs and the manner in which the upper torso and head were partially propped up against the grave side. This was because the bottom of the grave was too short. That no effort was made to rearrange the corpse once again implies haste. Even moving the body to the centre of the grave would have allowed the torso and head to be straightened and the body to be arranged more carefully. The haste may partially be explained by the fact that Richard's damaged body had already been on public display for several days in the height of summer, and was thus in poor condition.

The hands were crossed at the wrists, most likely right over left, and placed above the right pelvis. This is unusual for burials in medieval Leicester, although it is common elsewhere (Gilchrist \& Sloane 2005: 152; Gnanaratnam 2009: 121; Higgins et al. 2009: 264). Four different arrangements of the arms appear in other medieval sites in Leicester: 1) extended beside, or partially flexed over the pelvis; 2) conspicuously bent to a near right-angle over the abdomen; or 3) beyond right-angle over the chest, as if praying; and 4) crossed over the pelvis (i.e. one arm physically crossing the other, usually at the wrists). A recent study of 118 burials in the churchyard of St Michael's, a small parish church in Leicester's north-eastern quarter, shows that almost all of those buried belong to the first category; while only a very few belong to the second and third categories and even fewer to the fourth (Higgins et al. 2009: 264). Of 864 burials examined in the churchyard of St Peter's, also in Leicester's north-eastern quarter, a substantial majority belonged to the first category and few to the other three (Gnanaratnam 2009: 121). It is therefore possible that Richard III was buried with his hands bound. The position of the hands over the right pelvis appears awkward and unarranged, possibly because the torso was twisted to the left, pulling them off centre. If this is the case, it could result from the placement of the body in the grave rather than rearrangement afterwards. Yet it is surprising, considering their position, that if they were indeed unbound the right arm has not dropped to the side during or after interment.

We do not know what happened to Richard III's tomb. Modern disturbances above his grave had truncated deposits below the final floor and there are no historical records of its fate. Elsewhere in the choir and presbytery there is evidence that tombs and grave slabs were deliberately removed during the demolition of the church and that was probably the fate of Richard's tomb as well. 


\section{The skeleton of King Richard III}

The skeleton is in good condition apart from the feet, which are missing as a result of later disturbance, some of which was recorded to within $90 \mathrm{~mm}$ of the skeleton's lower limbs. There was no evidence of substantial post-mortem bone displacement, and the position of the vertebrae in the ground clearly reflected their position in life and was not a product of the awkward burial position.

Stable isotope analysis carried out during radiocarbon dating shows that the individual had a high protein diet, including significant amounts of seafood (amounting to some 25 per cent of the diet), suggesting high status. More detailed isotopic analysis is in progress. The ${ }^{14} \mathrm{C}$ evidence provides a modelled date of death of $c$ al $A D$ 1456-1530 (at 95.4\% probability), consistent with an individual who died in 1485 .

The individual is male, with a gracile build, in his late 20 s to late 30 s, compatible with Richard's known age at death of 32 . He had severe idiopathic adolescent-onset scoliosis. This may have been progressive and would have put additional strain on the heart and lungs, possibly causing shortness of breath and pain, although not all scoliosis sufferers experience pain from their condition. Unaffected by scoliosis, he would have stood around $5 \mathrm{ft} 8 \mathrm{in}$ $(1.73 \mathrm{~m})$ tall, above average height for a medieval man, though his apparent height might have decreased as he grew older and his disability may have lifted his right shoulder higher than his left. This is consistent with the few contemporary reports of Richard III's physical appearance (Rous 1745 [1486]: 216).

Ten peri-mortem wounds have been identified on the remains, eight on the skull and two on the post-cranial skeleton. Two large wounds underneath the back of the skull, consistent with a halberd and a sword blow, are likely to have been fatal. A third, smaller, penetrating wound to the top of the skull is more enigmatic, but may have been caused by a sharp blow from a pointed weapon, such as a dagger, on the crown of the head. Other wounds were more superficial and none of the skull injuries could have been inflicted on someone wearing a helmet of the type favoured in the late fifteenth century. Two wounds, a cut on a right rib and a cut to the right pelvis typical of a thrust through the right buttock, are again unlikely to have been inflicted on someone wearing armour. These, along with two wounds to the face, may be 'humiliation injuries' delivered after death. Similar injuries on skeletons from Towton (Fiorato et al. 2007; Foarde \& Morris 2012: 87-88), victims of an earlier battle in the Wars of the Roses, have been compared with those on Richard III's bones, and there appear to be some interesting differences in character, which will be treated in the forthcoming publication of the osteoarchaeology by Jo Appleby and colleagues.

The genealogical link between the two modern-day descendants and Richard III has also been verified. Initial analysis of the mitochondrial DNA has revealed a match between sequences in the control region of the mtDNA from the skeleton and two direct descendants of Richard III's sister, Anne of York, through the female line. All three also share a type of mtDNA that is relatively rare in the population of Europe, so it is highly unlikely that the match is coincidental. Further genetic research will not change these conclusions, and full results will be published when the analysis is completed by Turi King.

(C) Antiquity Publications Ltd. 


\section{Conclusion}

At this stage we have discovered enough of the plan of the Grey Friars precinct to feel confident that we have identified parts of the eastern range, the chapter house and the eastern end of the church, including the transition between the choir and the presbytery. This means that the hastily constructed grave in Trench 1 is certainly in the place indicated by the fifteenth- and sixteenth-century written sources as the tomb of King Richard III. The radiocarbon dates, evidence on the male skeleton of severe scoliosis, trauma consistent with injuries in battle and specific peri-mortem 'humiliation injuries', combined with the a mtDNA match with two independent, well-verified matrilineal descendants, all point clearly to the identification of this individual as King Richard III. Indeed, it is difficult to explain the combined evidence as anyone else.

This result is the most important one for our non-specialist partners, as well as for millions of people around the world, and addresses their key questions. However, the burial of King Richard III is only one episode in the life of an establishment that served Leicester for 300 years. There are many pressing archaeological questions still to address, and many new questions raised. Further evidence of the date, character of construction and extent of the church and other buildings will be sought in a further season of excavation in 2013 . The sequence of flooring in the eastern end of the church indicates a potentially complex biography for this building, which only further investigation will resolve. The extent to which the friary was refashioned for either functional or social reasons remains unknown: is this one of the earliest brick buildings in Leicester, and was the church significantly more elaborate than other structures on the site? Further exploration of the activities of the Grey Friars, if evidence for other buildings can be found, might help us understand better the role of the friars in the life of the medieval town. Also, investigation of the Dissolution period deposits, where these survive, might offer useful information about the physical and social processes of dissolving and dismantling monastic establishments under Henry VIII.

It is clear from this account that to some extent academic research questions coincide with the questions of our non-specialist partners and the wider public, but they are not identical. However, that does not mean that we as archaeologists should dismiss the questions of wider audiences as not worth asking. We have demonstrated that a project like Grey Friars, where academics, local authorities and amateur enthusiasts work together, can produce answers and benefits for all.

\section{Acknowledgements}

Thanks are due to the University of Leicester, the Richard III Society, Leicester Shire Promotions, Leicester City Council and everyone else involved in the project.

\section{References}

Austrums, R. 2011. Geophysical survey report: Greyfriars church, Leicester (Report J2934). Report prepared for Stratascan, Upton-upon-Severn.

BALDWIN, D. 1986. King Richard's grave in Leicester. Transactions of the Leicestershire Archaeological and Historical Society 60: 21-24.
Billson, C.J. 1920. Medieval Leicester. Leicester: Edgar Backus.

BL Harley MS 542. Richard ye third his deathe by ye Lord Stanley: ff. 31-34. Unpublished manuscript in the British Library, London.

BuCKLeY, R., J. STORY \& J. Bourne. 2006. Leicester Abbey: medieval history, archaeology and manuscript studies. Leicester: Leicestershire Archaeological and Historical Society. 
Calendar of the Close Rolls 1254-56. 1931. Calendar of the Close Rolls preserved in the Public Record Office: Henry III vol. IX A.D. 1254-1256. London: Her Majesty's Stationery Office.

CONNOR, A. \& R. BUCKLEY. 1999. Roman and medieval occupation in Causeway Lane, Leicester (Leicester Archaeology Monographs 5). Leicester: University of Leicester.

CourTney, P. 1998. Saxon and medieval Leicester: the making of a medieval landscape. Transactions of the Leicestershire Archaeological and Historical Society 72: $110-45$.

DudAY, H. 2009. The archaeology of the dead: lectures in archaeothanatology. Oxford: Oxbow.

DYER, A. 2000. Appendix: ranking lists of English medieval towns, in D. Palliser (ed.) The Cambridge urban history of Britain, Volume 1: 600-1540: 747-70. Cambridge: Cambridge University Press.

Fiorato, V., A. Boylston \& C. KNÜsel (ed.). 2007. Blood red roses: the archaeology of a mass grave from the Battle of Towton AD 1461. Oxford: Oxbow.

FOARDE, G. \& R. MORRIS. 2012. The archaeology of English battlefields: conflict in the pre-industrial landscape (CBA Research Report 168). York: Council for British Archaeology.

Gilchrist, R. \& B. SLOANE. 2005. Requiem: the medieval monastic cemetery in Britain. London: Museum of London Archaeology Service.

GLASSCOCK, R. 1975. The lay subsidy of 1334 (Records of Social and Economic History, new series II). London: The British Academy \& Oxford University Press.

Gnanaratnam, A. 2009. The excavation of St Peter's Church and graveyard, Vaughan Way, Leicester 2004-2006, Volume 1: stratigraphic sequence (Report 2009-156). Report prepared for ULAS, Leicester.

Greene, J.P. 1992. Medieval monasteries. Leicester: Leicester University Press.

HaLle, E. 1970 [1550]. The union of the two noble families of Lancaster and York. Menston: Scolar.

Higgins, T., M. Morris \& D. STONe. 2009. Life and death in Leicester's north-east quarter: excavation of a Roman town house and medieval parish church at Vine Street, Leicester 2004-2006. Volumes 1 \& 2 (Report 2009-134). Report prepared for ULAS, Leicester.

HunT, L. 2011. An archaeological desk-based assessment for land at Greyfriars, St Martin's, Leicester (NGR: SK 585 043) (Report 2011-038). Report prepared for ULAS, Leicester.
JAMES, T. 1997. Excavations at Carmarthen Greyfriars, 1983-1990. Medieval Archaeology 41: 100-94.

LiTTLE, A.G. 1951. Fratris Thomae vulgo dicti de Eccleston: tractatus de adventu Fratrum Minorum in Angliam. Manchester: Manchester University Press.

LUCAS, J.N. 1980-81. The debris of history: an archaeological survey of Leicester. Transactions of the Leicestershire Archaeological and Historical Society 55: $1-9$.

MARTIN, A. 1937. Franciscan architecture in England (British Society for Franciscan Studies 18). Manchester: The University Press.

MARX, W. (ed.). 2003. An English chronicle 1377-1461. Woodbridge: Boydell.

Mellor, J. \& T. PeArCe. 1981. The Austin friars, Leicester (CBA Research Report 35). London: Council for British Archaeology.

Morris, M. 2013. The Greyfriars Project: the archaeological search for the last known resting place of King Richard III, Grey Friars, Leicester (Report 2013-013). Report prepared for ULAS, Leicester.

NiCHOLS, J. 1815. The history and antiquities of the county of Leicester: Volume I, part II. London: Nichols, Son \& Bentley.

O'SULLIVAN, D. 2013a. In the company of the preachers: the archaeology of medieval friaries in England and Wales (Leicester Archaeology Monograph 23). Leicester: University of Leicester.

O'Sullivan, D. 2013b. Burial of the Christian dead in the later Middle Ages, in S. Tarlow \& L. Nilsson Stutz (ed.) The Oxford handbook of the archaeology of death and burial. Oxford: Oxford University Press.

Rous, J. 1745 [1486]. Joannis Rossi antiquiarii Warwicensis Historia Regum Angliae. Oxford: Theatro Sheldoniano, impensis J. Fletcher \& J. Pote.

SPEED, J. 1611. The history of Great Britaine under the conquests of ye Romans, Saxons, Danes and Normans. London: William Hall \& William Beale.

VergIL, P. 1972 [1555]. Historia Anglica. Menston: Scolar.

Received: 18 February 2013; Accepted: 26 February 2013; Revised: 12 March 2013

(C) Antiquity Publications Ltd. 